International Journal of Physical Sciences and Engineering
Available online at www.sciencescholar.us
Vol. 4 No. 1, April 2020, pages: 29-38
e-ISSN : 2550-6943, p-ISSN : 2550-6951
https://doi.org/10.29332/ijpse.v4n1.423

\title{
Design and construction of an industrial ship conditioning system \\ D CrossMark
}

\section{Ricardo Fabricio Muñoz Farfána, Telly Yarita Macías Zambrano ${ }^{b}$, Fausto Roberto Andrade Badilloc, Adrián Adalberto Hernández Solís ${ }^{d}$}

Manuscript submitted: 09 February 2020, Manuscript revised: 27 March 2020, Accepted for publication: 18 April 2010

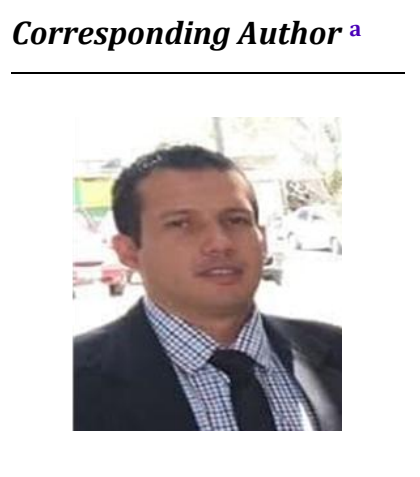

Keywords

conditioning;

efficiency energetic;

evaporative;

productive performance;

thermal comfort;

\begin{abstract}
This project is based on the design and construction of an industrial air conditioning system for the improvement of the working thermal comfort of workers that for various reasons there is the trend of the increase in body temperature are these by machines, equipment or the same work activities, which affects the productive performance and possible health risks. During development, the selection of mechanical equipment such as the fan, water pump, ventilation transport ducts is studied with high rates of energy efficiency. In the light of the above, the environmental economic partner alternative is chosen to implement the evaporative conditioning system, conducive to working in open places to lower the temperature by labor and technology installed in the production areas, as well as the extraction of fumes derived from production processes. The importance of the evaporative conditioning system is to derive the appropriate mechanisms to take advantage of the surface heat transfer of a panel and copper and aluminum coil using water, and thus take advantage of its temperature differential reaching $25^{\circ} \mathrm{C}$, with an average humidity of $66 \%$ and energy consumption of $0.29 \mathrm{KW} / \mathrm{h}$. To obtain results, the experimental field method, random cluster sampling, application of experimental observation sheets for the survey of diagnostic information of the current situation of the medium and equipment was applied.
\end{abstract}

International Journal of Physical Sciences and Engineering (C) 2020. This is an open access article under the CC BY-NC-ND license (https://creativecommons.org/licenses/by-nc-nd/4.0/).

\section{Contents}

Abstract

1 Introduction

2 Materials and Methods

3 Results and Discussions

a Instituto Superior Tecnológico Paulo Emilio Macías, Portoviejo, Ecuador

b Instituto Superior Tecnológico Paulo Emilio Macías, Portoviejo, Ecuador

c Instituto Superior Tecnológico Paulo Emilio Macías, Portoviejo, Ecuador

d Instituto Superior Tecnológico Paulo Emilio Macías, Portoviejo, Ecuador 
4

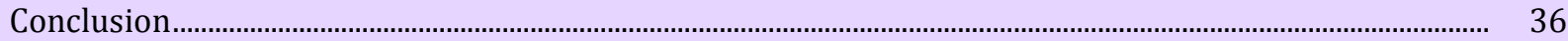

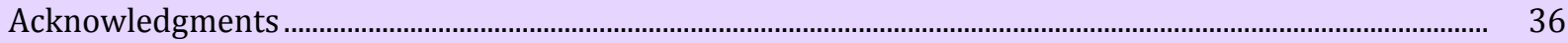

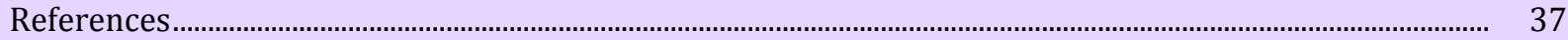

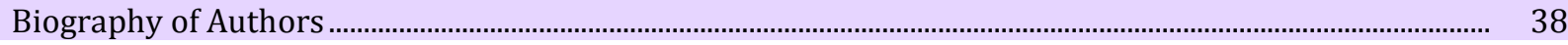

\section{Introduction}

Evaporative type conditioning is a natural phenomenon that is present in the environment due to the contact that water has with the surrounding air achieving the exchange of temperature between the two sources, acquiring a reduction of final temperature (Flores, 2011). Thermal comfort is important within the industrial environment and service, as continuous technological advancement makes it essential to understand and operate eco-sustainable equipment or systems providing abiotic resources (Hidalgo \& Pérez, 2016; Özdil et al., 2007; Sharma \& Ali, 1986; Nicol \& Humphreys, 2002; Puteh et al., 2012).

Executive Decree 2393 of the Workers' Safety and Health Regulation in Article 54 tells us that in working environments due to the effect of machines and work in production processes should not exceed the maximum permissible temperature values for the worker who is between 35 and $37^{\circ} \mathrm{C}$, and if this temperature has to increase from incorporating insulators for the reduction of the heat of the machines or implementing air conditioning systems in the enclosures (IESS, 1986). In the summer season, high temperatures are specifically reached, in industrial activity as in social services, around $34 \mathrm{oC}$ average heat, the temperature of the enclosure between 20 and $27^{\circ} \mathrm{C}$ and humidity between 30 and $70 \%$; smoke and general environmental characteristics characterize hard working hours and tiredness achieving the decrease in the production of workers, these aspects being important to solve to achieve an adequate level of competitive products and also respond to local and international environmental legislation (Company, 2016). On the other hand, it is important to mention that these evaporative systems fulfill the function of aerators and coolers in production areas (Flores et al., 2011), with high-efficiency parameters correlating with energy efficiency regulations by the European Commission (Olivares, 2017; Kuznik et al., 2008; Sun et al., 2004; Martens, 1998), which is essential in many cases for the generation of gases products from manufacturing processes which in turn makes potential sinks dangerous to health.

\section{Materials and Methods}

This research was carried out in the city of Portoviejo - Manabí - Ecuador, position $341 \mathrm{n}, 170 \mathrm{ft}$ height, $1 \mathrm{~atm}$ atmospheric pressure; in the facilities of the Instituto Superior Tecnológico Paulo Emilio Macías (Farfán et al., 2019), with an experimental design based on several tests of the test at variable reason interval, applied to a conditioning system that is intended to reach temperatures from $35^{\circ} \mathrm{C}$ max. $24.5^{\circ} \mathrm{C} . \mathrm{min}$.

\section{Results and Discussions}

To achieve this goal, the materials described in Table 1 were selected below:

Table 1

Materials and equipment for the development of the industrial and commercial conditioning system

\begin{tabular}{ll}
\hline Description & Amount \\
\hline Panel - Serpentine (copper /aluminium) & 1 \\
Iron galv.1220x2440x0.90mm & 5 \\
1/2 Hp 220V Induced Fan & 1 \\
Water Pump 37.3 W, 127 V. AQUA 45W & 1 \\
1/8 rivets & 1 \\
Ventoletas 1/8 X L & 32 \\
\hline
\end{tabular}




\begin{tabular}{ll} 
Contactor assistants & 2 \\
9-amp 220v contactors & 2 \\
Temperature and humidity sensor & 1 \\
Arduino UNO Controller & 1 \\
Selector & 1 \\
Pilot Lights & 3 \\
Lcd & 1 \\
Control cabinet and force box & 1 \\
Cable \#12 & $10 \mathrm{mts} \times 3$ lines \\
$1 / 4 x 90 "$ elbow & 2 \\
Clamps of $1 / 2$ & 2 \\
Insulating tape. & 1 \\
$1 / 4 x 2.5$ plastigam tube & 4 \\
Silicone & 2 \\
Cutting disc $41 / 2 " x 1 / 16 "$. & 2 \\
\hline
\end{tabular}

\section{Description of the evaporative conditioning system}

Industrial conditioning systems have a heat transfer center type coil panel, flowing inside the water and on the outside is a water pump that bathes from the top to the bottom of the panel, accumulating in a reserve pool to meet the closed cycle; on the other hand, for the aforementioned recirculation, it will be done using a low-consumption submersible water pump (ACR Latin America, 2019; Hanus et al., 1987; Sun, 1997; Kinsara et al., 1996).

The fan is located at the bottom of the heart center which can operate in ventilation and cooler mode. For air transport, a piping system was used, with thermal insulation of glass wool around it to reduce heat loss per wall and have a good energy efficiency coefficient. (Commercial steel of Ecuador S.A., 2019). The temperature and relative humidity monitoring system is made by an Arduino Uno controller through sensors equipped in the center of the main duct and its display on an LCD screen that is located in the control and force enclosure. Then, in Table (Arduino Corporation, 2019). In table 2 is show the instrumentation used for data-taking is cited.

Table 2

Instrumentation specifications

\begin{tabular}{|c|c|}
\hline Description & Technical characteristics \\
\hline \multirow[t]{2}{*}{ Temperature and humidity meter, dew point } & Proskit MT-4616 \\
\hline & PEAK METER MS6508 \\
\hline \multirow[t]{2}{*}{ Wet-bulb } & Rank: -20 to 60 degrees $\mathrm{C}$ \\
\hline & $\begin{array}{l}4 \text { degrees Fahrenheit/140.5 degrees Fahrenheit } \\
\text { RH: } 0 \text { to } 100 \% \text {, accuracy } 2 \%\end{array}$ \\
\hline \multirow[t]{2}{*}{ Liquid and Solid Temperature Meter } & TA288 Stainless steel probe \\
\hline & Range: $50 \mathrm{oC}$ and $300 \mathrm{oC}$ \\
\hline Wind speed meter & Specifications \\
\hline \multirow[t]{2}{*}{ Anemometer } & $\begin{array}{l}\text { Air speed } 0-30 \mathrm{~m} / \mathrm{s}, 0-90 \mathrm{~km} / \mathrm{h}, 0-5860 \mathrm{ft} / \mathrm{min}, 0 \\
-65 \mathrm{mph}\end{array}$ \\
\hline & $\begin{array}{l}\text { Resolution: } \quad 0.1 \mathrm{~m} / \mathrm{s}, \quad 0.3 \mathrm{~km} / \mathrm{h} \text {, } \\
0.2 \mathrm{mphPrecision} \text { speed: }+/-5 \%\end{array}$ \\
\hline \multirow[t]{2}{*}{ Sonómetro digital Tipo II ANSI S1.4 IEC 651} & Acoustic pressure range: $30-130 \mathrm{dbA}$ \\
\hline & $\begin{array}{l}\text { Frequency range: } 31.5 \mathrm{~Hz}-8.5 \mathrm{Khz} \\
\text { Accuracy range: }+-1.5 \%\end{array}$ \\
\hline
\end{tabular}

Farfán, R. F. M., Zambrano, T. Y. M., Badillo, F. R. A., \& Solís, A. A. H. (2020). Design and construction of an industrial ship conditioning system. International Journal of Physical Sciences and Engineering, 4(1), 29-38. https://doi.org/10.29332/ijpse.v4n1.423 
Figure 1 shows the Mechanical Scheme of the Evaporative Conditioning System

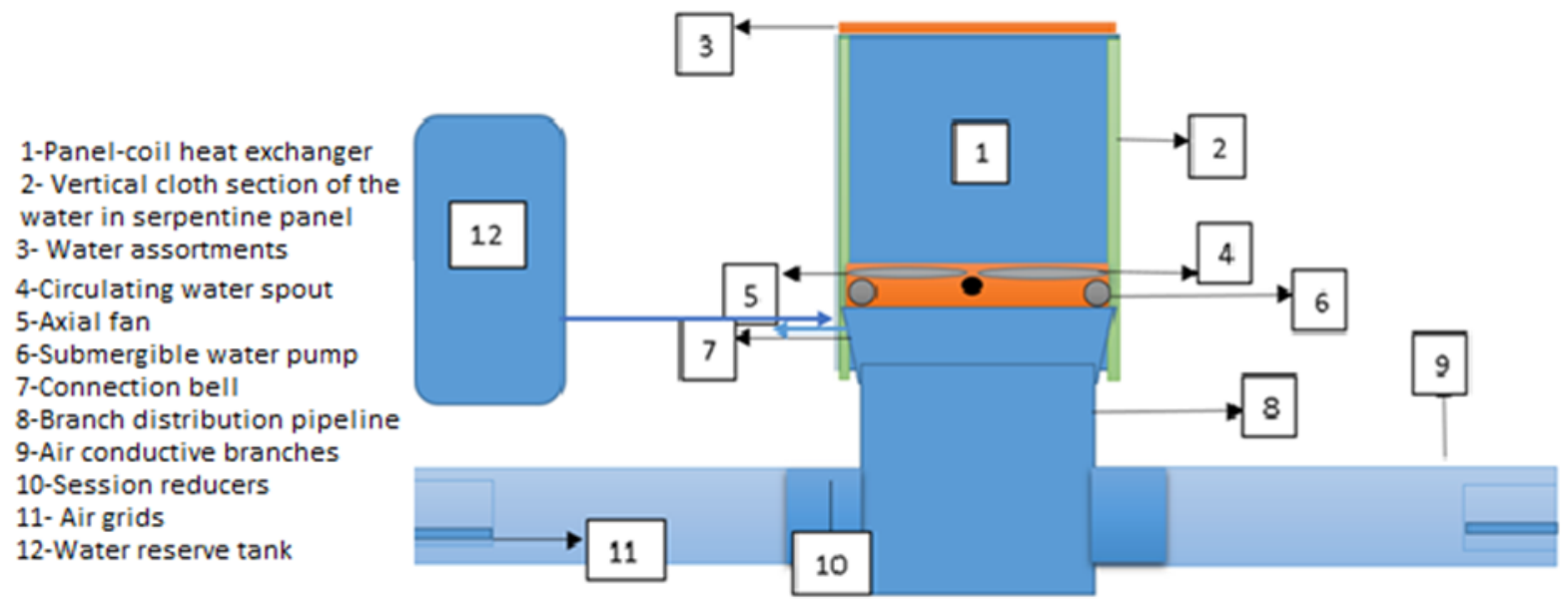

Figure 1. Mechanical scheme of the evaporative conditioning system

Figure 2 shows images of the control panel and in (B) the item of ventilation and pumping.
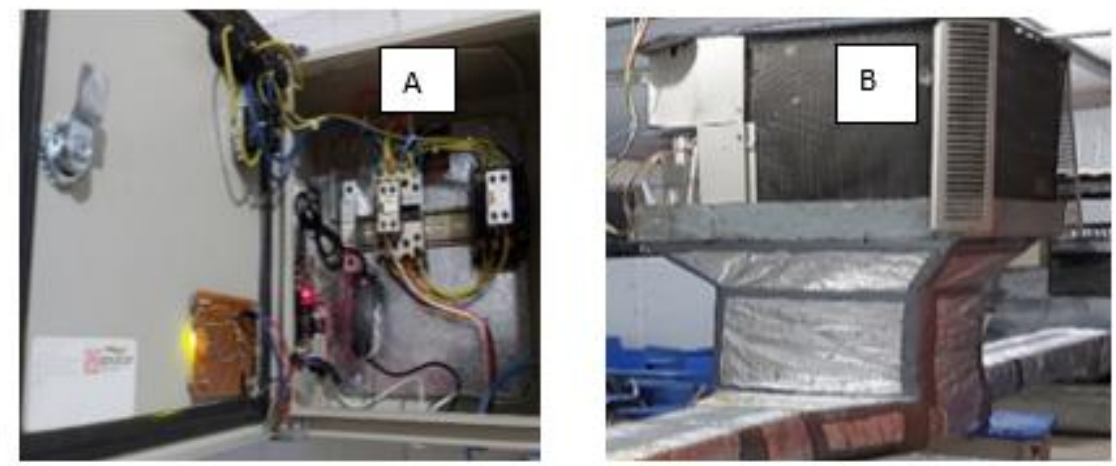

Figure 2. Cabinet of control and Power

In Figure 3, the mechanical equipment of the system is observed, in (Av) LCD Viewer
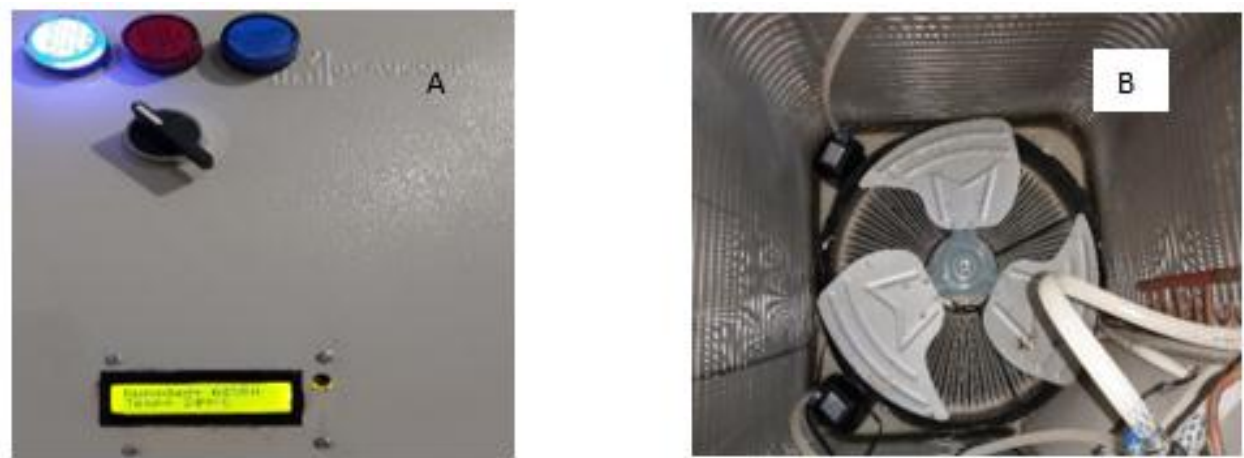

Figure 3. Mechanical system equipment

The technical operating data of the conditioning system were obtained from the experimentation phase. In figure 4, the ambient temperature values are displayed. 


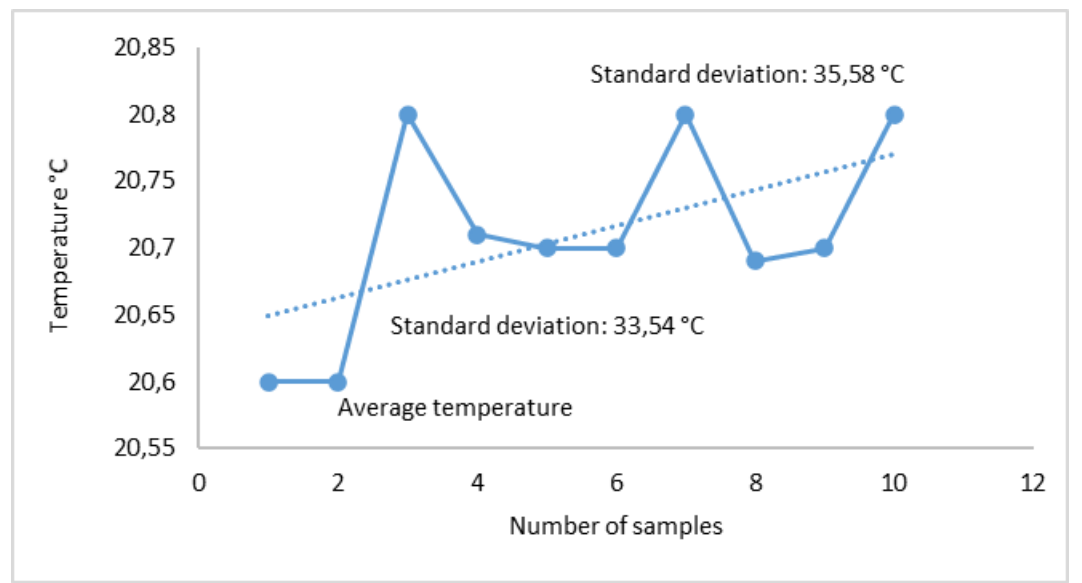

Figure 4. Ambient temperature

Figure 5. details the relative ambient humidity.

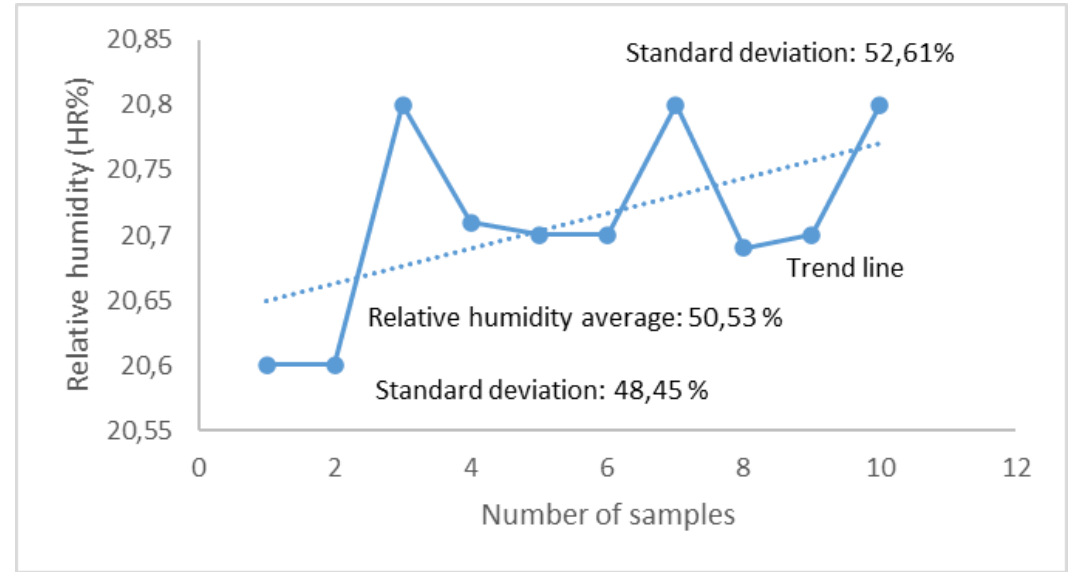

Figure 5. Relative ambient humidity

Figure 6. Shows the results obtained in the measurements of Temperature Environmental Spray Point.

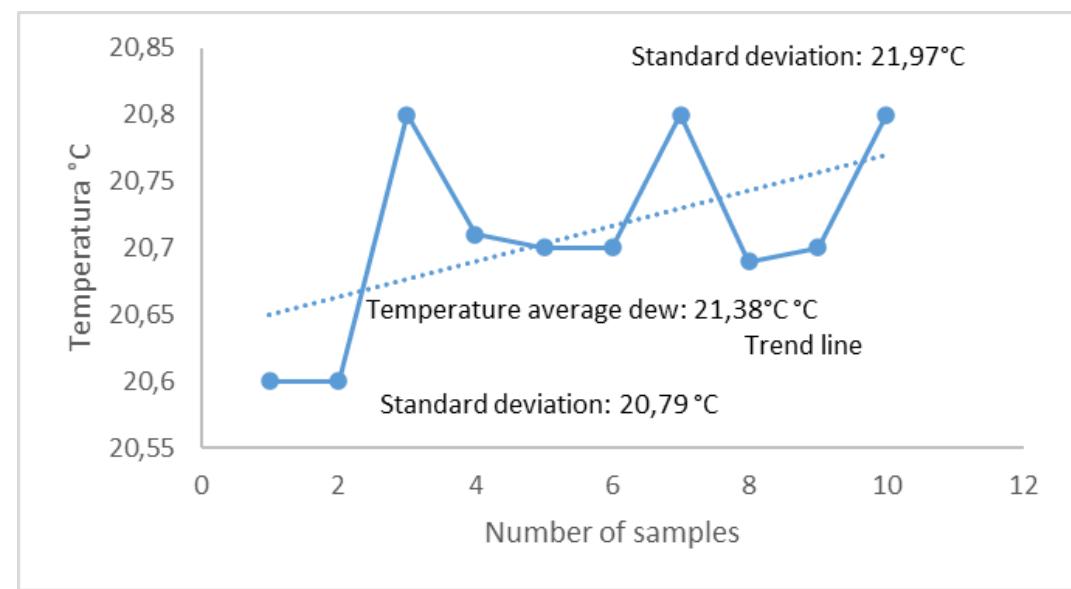

Figure 6. Temperature Environmental Spray Point

Farfán, R. F. M., Zambrano, T. Y. M., Badillo, F. R. A., \& Solís, A. A. H. (2020). Design and construction of an industrial ship conditioning system. International Journal of Physical Sciences and Engineering, 4(1), 29-38. https://doi.org/10.29332/ijpse.v4n1.423 
Figure 7. Shows the temperature of the ambient wet bulb

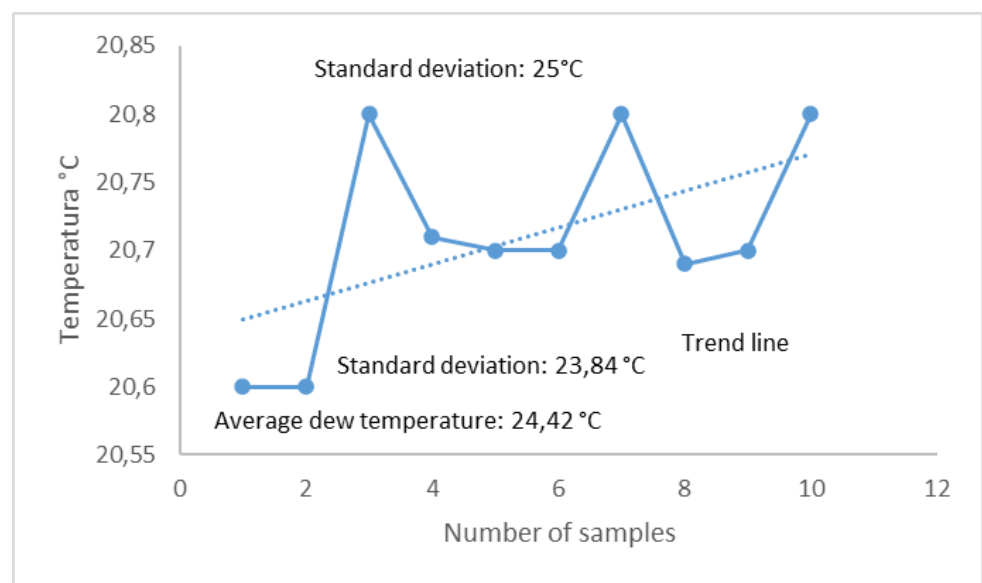

Figure 7. Ambient Wet Bulb Temperature

Figure 8. Shows the air temperature of the system.

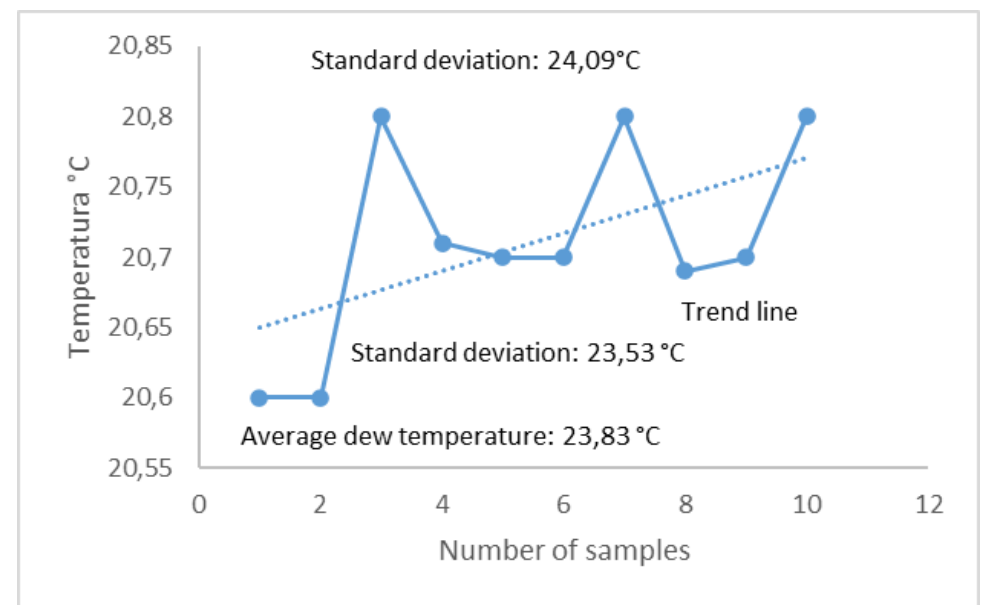

Figure 8. System air temperature

Figure 9. Shows the relative humidity of the System.

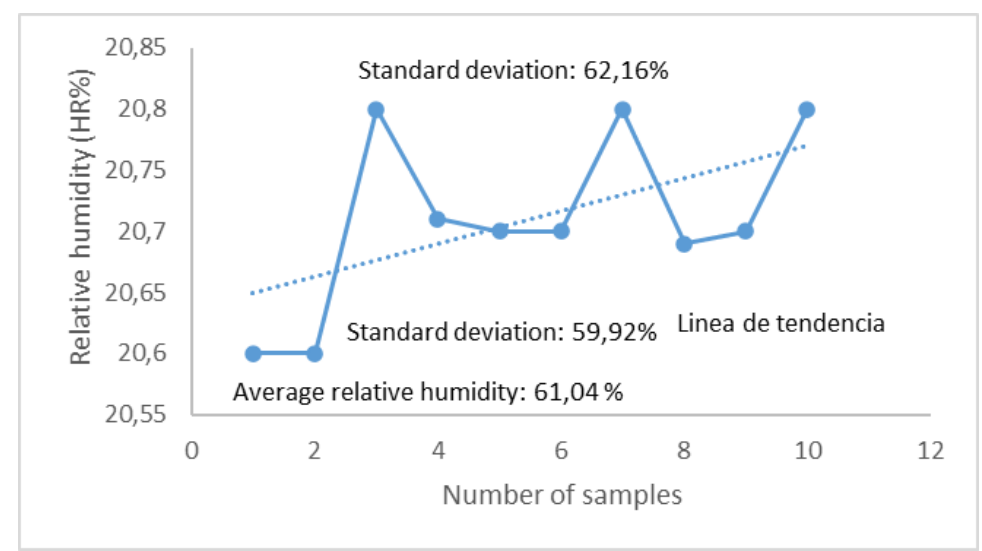

Figure 9. Relative humidity of the system 
Figure 10. Shows the System spray Temperature.

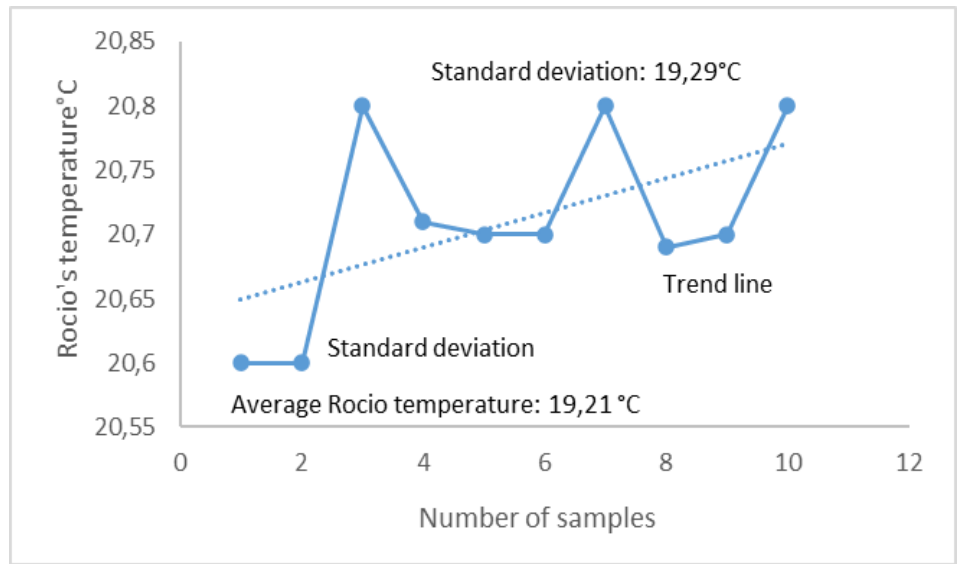

Figure 10. System spray Temperature

Figure 11. Shows the Wet System Bulb Temperature.

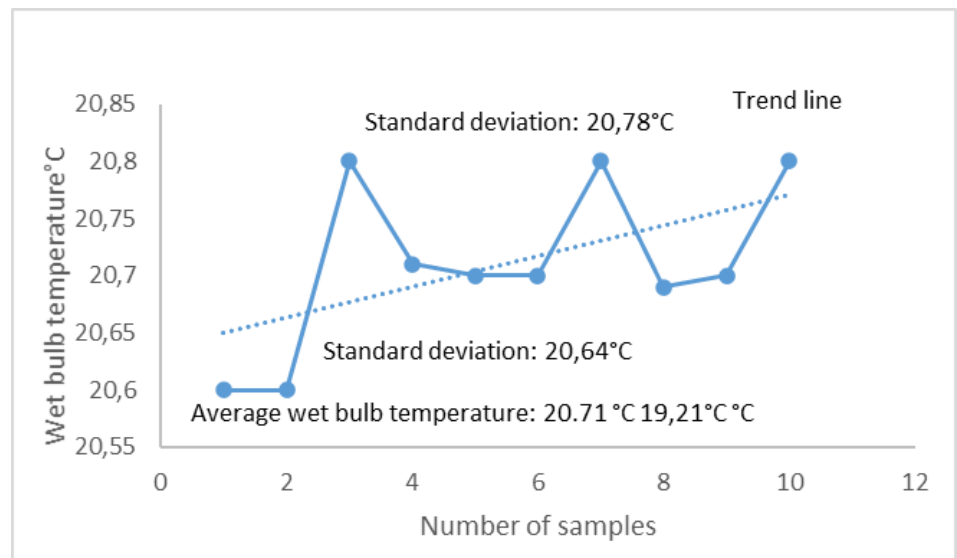

Figure 11. Wet System Bulb Temperature

Table 3 describes the energy efficiency parameters of the conditioning equipment.

Table 3

Energy Efficiency Parameters

\begin{tabular}{|c|c|c|c|c|c|}
\hline Unit & $\begin{array}{l}\text { Consumption } \\
\text { at (KWh) }\end{array}$ & & $\begin{array}{l}\text { Consumption } \\
(\mathrm{KW} / \mathrm{h})\end{array}$ & $\begin{array}{l}\text { Annual } \\
\text { Consumption } \\
\text { (KW year) }\end{array}$ & $\begin{array}{l}\text { Industrial Cost } \\
(\$)-(\mathrm{KW})\end{array}$ \\
\hline Axial fan & 0.22 & 0.22 & & & 0.072 \\
\hline Water Pump & $0.036 \times 2$ & 0.072 & & & \\
\hline Total Consumption & & 0.29 & 6.96 & 2540.4 & \\
\hline
\end{tabular}

Farfán, R. F. M., Zambrano, T. Y. M., Badillo, F. R. A., \& Solís, A. A. H. (2020). Design and construction of an industrial ship conditioning system. International Journal of Physical Sciences and Engineering, 4(1), 29-38. https://doi.org/10.29332/ijpse.v4n1.423 
Table 4 describes the proposed technical specifications of the equipment.

Table 4

Technical specifications of the equipment

\begin{tabular}{ll}
\hline Design conditions: & \\
\hline Country: & Ecuador \\
Altitude: & 100 meters above sea level \\
Average outdoor temperature: & $32.5^{\circ} \mathrm{C}$ \\
HR: & $50.5 \%$ \\
Interior design temperature: & 27 o \\
Enclosure area: & $20 \mathrm{~m}^{2}$ \\
Temperature & $24 \mathrm{a} 25^{\circ} \mathrm{C}$ \\
Relative Humidity of the system & $60 \%$ \\
Wet Bulb Temperature & $20.71^{\circ} \mathrm{C}$ \\
Temperature Dew Point & $19.21^{\circ} \mathrm{C}$ \\
Energy consumption & $0.29 \mathrm{KW} \mathrm{h}$ \\
Conditioning capacity & $20 \mathrm{~m}^{2}$ \\
Cooling power & $2.1 \mathrm{KW}$ \\
Voltage & $110 / 220 \mathrm{~V}$ single-phase \\
Acoustic pressure level & $80 \mathrm{dBA}$ \\
Water consumption & $3 \mathrm{~L} / \mathrm{h}$ \\
\hline
\end{tabular}

\section{Conclusion}

Environmentally friendly system (eco-friendly) Low energy consumption system with 0.44 KWh. Low decibel of operation reducing hearing pollution Low-cost maintenance and operation system. Friendly to hearing pollution. (8 hours of noise exposure).

\section{Acknowledgments}

A thank you to the management of the Polytechnic and the editors of the magazine for allowing us to disseminate the results obtained. 


\section{References}

Acero comercial del Ecuador S.A. (2019, enero 15). Acero comercial del Ecuador.

ACR latino América. (2019). acrlatinoamerica.com. Arduino Corporation. (2019).

Company, B. d. (2016). Enfriadores evaporativos. From Biocool de termigo: www.biocool.es

Farfán, R. F. M., Zambrano, T. Y. M., Valencia, V. P. Z., \& Sosa, V. M. D. (2019). Design and construction of a cold production simulator system: chiller. International Journal of Physical Sciences and Engineering, 3(3), 3140. https://doi.org/10.29332/ijpse.v3n3.367

Flores, M. (2011). Acondicionamiento de espacios con enfriamiento evaporativo. Ingenieria mecánica tecnológica, 4(1).

Flores, M., Hernández, R., Rey, M., Velasco, G., \& Tejero, G. (2011). Acondicionamiento de espacios con Enfriamiento Evaporativo mediante ladrillos cerámicos. Ingeniería mecánica, tecnología y desarrollo, 4(1), 001-014.

Hanus, R., Kinnaert, M., \& Henrotte, J. L. (1987). Conditioning technique, a general anti-windup and bumpless transfer method. Automatica, 23(6), 729-739. https://doi.org/10.1016/0005-1098(87)90029-X

Hidalgo, D. B., \& Guerra, Y. P. (2016). Eficiencia energética en la climatización de edificaciones. Revista Publicando, 3(8), 218-238.

IESS, I. E. (1986). Decreto Ejecutivo 2393. Reglamento de seguridad y slud de los trabajadores y mejoramiento del medio ambiente de trabajo. Quito, Pichincha, Ecuador: Suplemento del Registro Oficial No.

Kinsara, A. A., Elsayed, M. M., \& Al-Rabghi, O. M. (1996). Proposed energy-efficient air-conditioning system using liquid desiccant. Applied Thermal Engineering, 16(10), 791-806. https://doi.org/10.1016/13594311(95)00090-9

Kuznik, F., Virgone, J., \& Roux, J. J. (2008). Energetic efficiency of room wall containing PCM wallboard: A fullscale experimental investigation. Energy and buildings, 40(2), 148-156. https://doi.org/10.1016/j.enbuild.2007.01.022

Martens, A. (1998). The energetic feasibility of CHP compared to the separate production of heat and power. Applied thermal engineering, 18(11), 935-946. https://doi.org/10.1016/S1359-4311(98)00026-X

Nicol, J. F., \& Humphreys, M. A. (2002). Adaptive thermal comfort and sustainable thermal standards for buildings. Energy and buildings, 34(6), 563-572. https://doi.org/10.1016/S0378-7788(02)00006-3

Olivares, A. (2017). Energy security in the European Union: a model to imitate?. International Studies (Santiago), 49 (187), 43-84. http://dx.doi.org/10.5354/0719-3769.2017.47027

Özdil, N., Marmaralı, A., \& Kretzschmar, S. D. (2007). Effect of yarn properties on thermal comfort of knitted fabrics. International journal of Thermal sciences, 46(12), 1318-1322. https://doi.org/10.1016/j.ijthermalsci.2006.12.002

Puteh, M., Ibrahim, M. H., Adnan, M., Che'Ahmad, C. N., \& Noh, N. M. (2012). Thermal comfort in classroom: constraints and issues. Procedia-Social and behavioral sciences, 46, 1834-1838. https://doi.org/10.1016/j.sbspro.2012.05.388

Sharma, M. R., \& Ali, S. (1986). Tropical summer index-a study of thermal comfort of Indian subjects. Building and Environment, 21(1), 11-24. https://doi.org/10.1016/0360-1323(86)90004-1

Sun, D. W. (1997). Solar powered combined ejector-vapour compression cycle for air conditioning and refrigeration. Energy Conversion and Management, 38(5), 479-491. https://doi.org/10.1016/S01968904(96)00063-5

Sun, Z. G., Wang, R. Z., \& Sun, W. Z. (2004). Energetic efficiency of a gas-engine-driven cooling and heating system. Applied thermal https://doi.org/10.1016/j.applthermaleng.2003.10.014

engineering, 24(5-6),

941-947.

Farfán, R. F. M., Zambrano, T. Y. M., Badillo, F. R. A., \& Solís, A. A. H. (2020). Design and construction of an industrial ship conditioning system. International Journal of Physical Sciences and Engineering, 4(1), 29-38. 


\section{Biography of Authors}

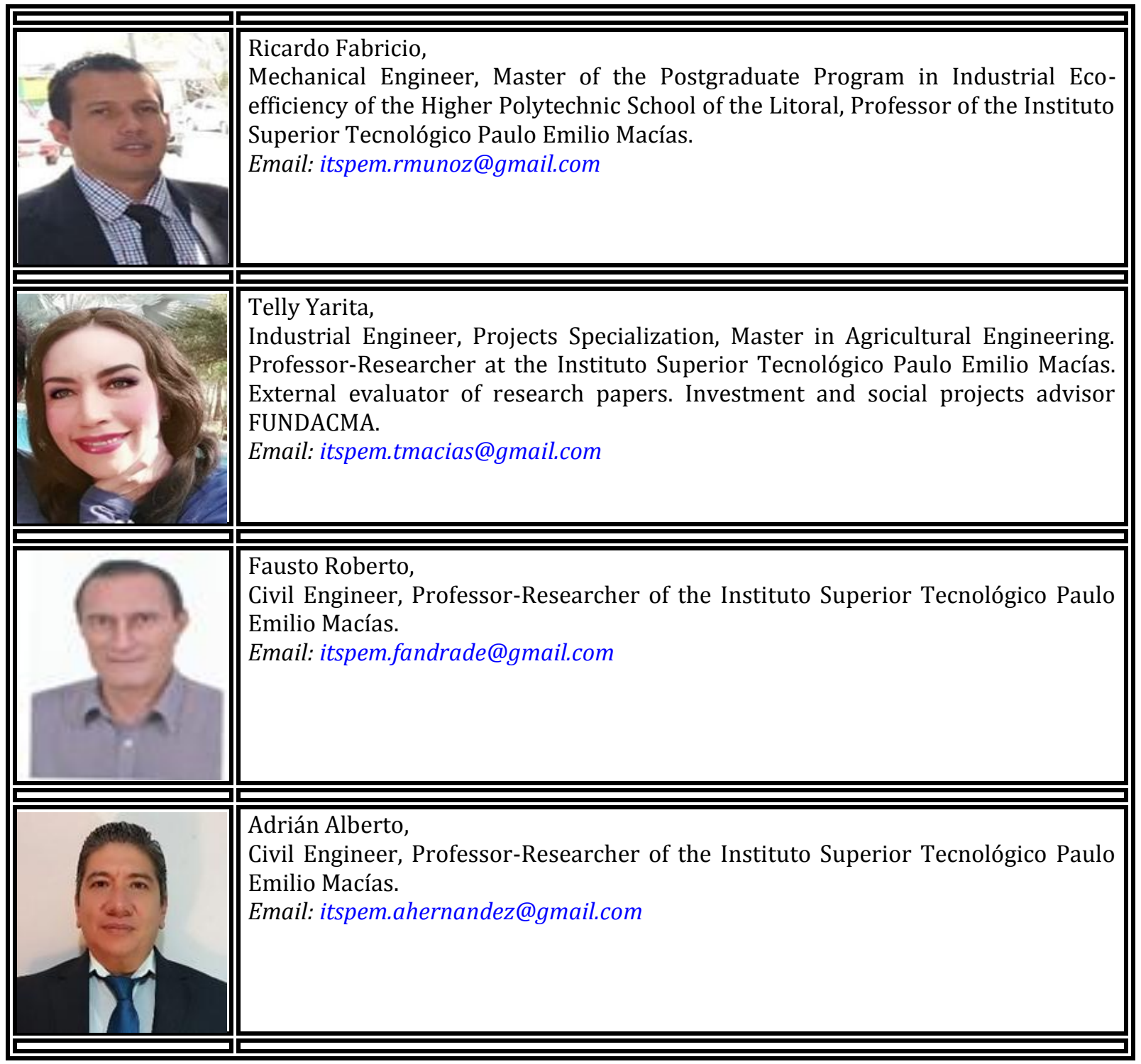

